\title{
Translating Humor: A Case of Censorship vs. Social Translation
}

\author{
A.Sirin Okyayuz, PhD \\ Bilkent University, Turkey
}

doi: 10.19044/esj.2016.v12n8p204 URL:http://dx.doi.org/10.19044/esj.2016.v12n8p204

\begin{abstract}
In Turkey, as in the case of other countries, due to developments in technology and the rise of the 'social translation' sector, audiences have the opportunity to watch TV shows, including sitcoms, with Turkish subtitles on a multitude of platforms. Although some of these platforms are TV channels, there are also alternatives presented by Internet sites. By virtue of the fact that there are different subtitlers of the same show, it becomes beneficial to study the work of professional translators vs. social translators, to understand their constraints and realities, as well as the differences between them. This study provides a comparative analysis of the two, within the context of the American sitcom Two and a Half Men.
\end{abstract}

Keywords: Audiovisual translation, subtitling, censorship, social translation, sitcom translation

\section{Introduction}

Turkish audiences have favourite sitcoms which they watch on a multitude of platforms such as cable TV, Turkish satellite television provider platforms, the Internet, and on DVD's. These sitcoms appeal to audiences who are young and educated, among others. There are three different types of sitcoms in Turkey: the Turkish sitcom (i.e., Avrupa Yakasi), the adapted sitcom (i.e., Dadl, a remake of The Nanny), and the translated sitcom of which there are dozens of examples. The translated sitcoms are almost always subtitled on the multiple platforms on which they are available.

It is important to underline that this study does not concentrate on the difficulties of subtitling or subtitling sitcoms, but it focuses on a comparison between the different versions produced by translators of different profiles working in different mediums. With this aim in mind, based on the scope of the study, it becomes necessary to pinpoint the essentials in sitcom subtitling and the constraints surrounding the different practices of subtitling studied. 
In this vein, Bucaria $(2007,237)$ sums up the difficulty of translation of sitcoms where punch lines are followed by a laugh track, which would make "the deletion of a funny remark impossible unless the laughter is also digitally omitted." This means that the translator of the sitcom is under constant pressure to say something funny. The sitcom is written to be funny. Thus, when this aspect is deleted or is not transferred to the target audience, the sitcom loses its appeal for the target viewers.

Bucaria (2007:251) also refers to general regulations on a national level and channels considerations that "leave little room to considerations about a respectful treatment of the original product." This basically translates into the fact that there are constraints placed on the translator (i.e., the use of a certain language, the omission of a certain reference, or the amount of time given to the subtitler).

Although, as with every translation, there are a matrix of concerns and realities surrounding the production of subtitles, these two issues are at the heart of translating sitcoms with a semblance of quality in Turkey. However, this is not to say that there are no good translations and translators. On the contrary, thanks to the translation and adaptations Turkey came to know this genre since the 1990's.

This well-liked genre has also gained an audience over the Internet in the last decade or so in Turkey. Therefore, this study is a comparative analysis of the translations of a sitcom by the professional institutional translators working for TV channels and social translators (the concept will be explained in further parts of the study) for Internet sites.

\section{Two and a Half Men came to Turkey}

Two and a Half Men was an American sitcom that began on CBS in September 2003, and ended in February 2015. It has a 7.2 /10 IMDb rating on average and was aired in over fifty countries ${ }^{54}$.

The show is about a selfish and hedonistic jingle writer, Charlie Harper, and his uptight brother, Alan, and Alan's son Jake. It is about the life led by the three as Alan moves into Charlie's house after his divorce. At the beginning of the ninth season, Charlie is replaced by Walden Schmidt, a billionaire who buys Charlie's house after his death and invites Alan and Charlie's long lost daughter to live with him, forming a tight knit surrogate family. The series mainly centres on the contrast between responsible vs. irresponsible, decent vs. indecent characters, and an outlandish, often promiscuous and funny lifestyle.

The twelfth season of the series, the season studied, was the final season. In this season, Walden decides to adopt a child. However, upon

\footnotetext{
${ }^{54}$ IMDb. com (Accessed June 30 2015). http://www.imdb.com/title/tt0369179/
} 
realising that the only way he can adopt is if he is married, he decides on a bogus gay marriage with Alan. The couple eventually adopt a child and subsequently divorce after finding the loves of their lives. Charlie is revealed to be alive, having been kept as a prisoner by his wife for four years. However, he escapes, but he later gets killed in the season finale.

Two and a Half Men was a success, rating among the top 10th through the 27th most watched shows in the USA and reaching millions of viewers all over the world (i.e., between 11-16 million in the USA only). The show also received 16 awards from the sector between the years 2004$2013^{55}$.

The official TV network in Turkey which holds the rights to Two and a Half Men is CNBC-e, a subsidiary of Doğuş Yayın Grubu ${ }^{56}$. CNBC-e was established in October 2000 and airs two distinct types of material. The morning session is reserved for business and finance, while the evening zone is reserved for entertainment. The channel, in cooperation with HBO, WB, MGM, Paramount, Bueno Vista, Sony Columbia, Fox and other broadcasters, airs subtitled famous American TV series ${ }^{57}$. Hence, Two and $a$ Half Men was aired in the evening zone in Turkey.

Consequently, other platforms through which Turkish viewers can watch this show are not legal. It has become a trend in Turkey in recent years to set-up Internet sites which survive through advertisements, especially for gambling and adult products among other things. International hit American TV series with Turkish subtitles can be downloaded from these websites. There are an abundance of such sites which include: Dizibox, Dizimag, Dizipub, Dizist, Dizigold, altyaz1.org etc. When taken off the web by authorities, they appear almost immediately under other names. These sites are popular, and, as can be verified from the uploaded dates and times of the shows, provide subtitled versions of shows shortly after the original airing (i.e., within 24-48 hours of the release in the USA).

There are many such sites around the world be it for sitcoms, anime, news, films etc. Moreover, these are diligently studied by translation scholars. Scholars such as McDonough Dolmaya (2012, 168) refer to crowdsourced translations as initiatives which are collaborative efforts to translate online content both by amateurs and professionals. On the other hand, O’Hagan $(2009,97)$ proposes the term ‘user-generated translation' to refer to "translation and localization undertaken by unspecified self-selected

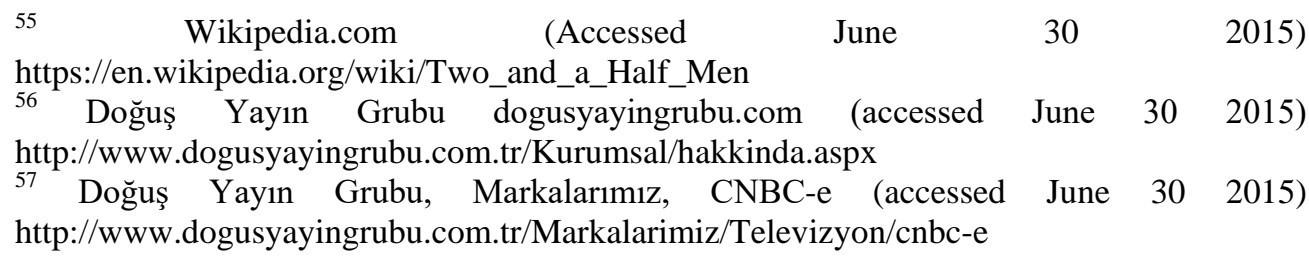


individuals and carried out based on free user participation in digital media spaces.” Dodd (2011) refers to crowdsourced translation as "a collaborative effort to translate content such as videos, software and written text either by enthusiastic amateurs or by professional translators.”

With reference to the study, within the context of the definitions, it would not be wrong to classify these subtitlers as 'social translators' such as those mentioned by the scholars above.

There is no institutional page one can click on to find information about these subtitlers. Information about who they are has to be gleaned from various sources that are available on the Internet. Therefore, current research on the Internet has yielded the following answers to some questions:

Who are these subtitlers? According to information from Gence (2009) who conducted interviews with some of these volunteers, these subtitlers generally prefer to use nicknames and not their real names. They are not employed by any organization and many of them seem to come from professions such as banking, information technology, graphic design, civil engineering etc. Furthermore, their ages range from early 20's to 50's. They state very clearly that "they do this as a hobby and do not earn any money." They spend 4-8 hours to subtitle a 40 minute episode. Many of them subtitle because they like the shows. Also, they only subtitle the shows that they like. They use the English subtitles, as well as the audiovisual recording that they download from the original to translate.

At this juncture, it becomes necessary to point out that subtitling sitcoms has become a less arduous task as dialogue lists can be downloaded by the subtitler. According to Bogucki (2009:56-57), the product of "amateur subtitling tends to be marred by translational error due to factors such as incomplete source texts," underlining that further study of amateur subtitling can only be meaningful if these subtitles are produced under conditions comparable with those of professional subtitling. Thus, it may be useful to point out that, due to practices such as subtitling for the hearing impaired in the source language, the subtitlers in question, as opposed to others who subtitle different genres of audiovisual material from different languages, have access to the dialogue lists from various sources over the Internet once the shows are broadcast in their country of origin in English. This makes the subtitling of this type of audiovisual product more efficient and perhaps even more appealing.

Who can become a member of this group? There seems to be several answers to this question. In one instance in answer to the question posed by a first timer on a chat platform for subtitlers, "Where do I apply to subtitle? Can I subtitle?” the answer is, “Go ahead. Who's stopping you?” (see Chat 1) The rest of the chat goes on to provide information like 'pick something someone else has not done and download it, download the English subtitles 
from the Internet.' The newcomer is also further referred to two online documents which contain the norms that the subtitler should abide by (see Chat 2).

There are also instances where enthusiasts state online that they would like to subtitle (see Chat 3) and provide their contact information so that the sites can contact them.

Other sites could be referred to as a closed group. Mesipuu (2010:16) defines a closed community of translators as a setting where the crowd is limited and the members are selected. Since this is a more exclusive community, certain obligations are placed on the translator, one of them being translation deadlines.

One of the more structured subtitlers groups, for example, has an online form that one fills out if they wish to subtitle. There are limitations like, "you have to have experience" and "you have to hand in your subtitles at a certain time." Subsequently, there is also information concerning payment like "you will get paid according to the popularity of the series and difficulty level of the translation", "you must not apply for financial reasons only", and "you can volunteer" with the implication that though the site mentioned seems more structured with formal applications and all, the essence is still the same, i.e., it is mostly volunteer work ${ }^{58}$. For example, in another case (see Chat 4), there is an application form for potential subtitlers and in addition to names and contact information the questions asked to the applicant are as follows: Have you subtitled before? Do you know how to use a subtitling program? Are you volunteering, or do you want to be paid? If you want to be paid, make us an offer like X TL for short and Y TL for long episodes. In conjunction with this, in another chat, a subtitler states that he asked for 50TL (17 euros) per episode and was refused because his bid was too high (see Chat 5).

Further examples are sites that make calls for subtitlers (see Chat 6). They pay 10TL (3.5 euros) for short series and 20TL (7 euros) for long series. They add that they are also open to volunteers who will subtitle for free, but only if they abide by the rule to hand in their subtitled versions within 24 hours.

How much money do these subtitlers receive per episode? Since there are several references to this issue in past questions, it may be estimated that when these subtitlers are paid, they make at most 20 euro per episode. However, more often than not, they claim "subtitlers do not earn money. It is volunteer work," (see Chat 7).

https://docs.google.com/forms/d/1sKoO82s8pJ3bXKsxszZphbWxz_VJUwoFvVFCe3VOa4 g/viewform 
Are others aware of the existence of these subtitlers and what are the motivations of the subtitlers? There are many Internet posts about this phenomenon, but two examples that explain the situation best are: "[...] everyone thinks they can do it, and they [meaning the sites] hand everyone work to subtitle. There are a lot of people who willingly do this for free just to watch the series beforehand and make a name for themselves," (see Chat 8). "[...] you get used, they expect you to hand in the subtitles as soon as possible, you get stressed and you get nothing in return [...]" (see Chat 8). Furthermore, there are also those who wish to "improve their English" (see Chat 9), "improve their translation skills" (see Chat 10), or "make a name for themselves and earn pocket money," (see Chat 11).

According to Hesselund (2014), there are multiple satisfying reasons why people contribute, the same applies to the social translation in the corpus studied. This seems to fit in with what Howe (2008:29) suggests, that people contribute, so everyone can realise their potential. Other times, they want to be a part of something important or interesting. In addition, other reasons include: the persons ambition, material incentives, belonging or being part of something, learning, and productive selfishness.

O’Hagen (2003) states that despite their dubious legal status, fan-subs have been in existence since the late 1980s; the same applies to these Internet sites which provide subtitled versions of American sitcoms in Turkish in the last decade or so.

Pym (2011:1) asks the question: "how does technology connect with the rise of the volunteer?" The answer in this case is that, for example, according to Bogucki (2009:50), inserting subtitles in a programme is easy even for the relatively inexperienced user. The younger generation in Turkey are technologically savvy and they seem to have a good command of subtitling programmes. Subtitle Workshop seems to be popular as it is referred to on the chat platforms. It is simple to use and does not require any additional tuning beyond entering the correct translation in the relevant subtitling box. These individuals then use these programmes to subtitle the shows that they want. Also, many of them subtitle many shows or multiple episodes of the same show, and one can conclude that it must be satisfying for them.

In accordance with the research conducted on alexa.com (Actionable Analytics for the Web), an Internet site allowing users to find the ranking of Internet sites around the world, there are an average of five of these sites within the top two hundred sites in Turkey ${ }^{59}$. Hence, this shows the popularity of these sites. In some cases, they rank higher then popular online

\footnotetext{
59 Alexa. An amazon.com company. Top sites, By Country (Accessed June 30 2015) http://www.alexa.com/topsites/countries/TR
} 
shopping, news, official application, online banking sites etc. The top two sites are Dizibox (Ranking 83) and Dizipub (Ranking 125). The statistics are as given in Figure 1 and Figure 2 below. ${ }^{60}$

Figure 1. Dixibox rating

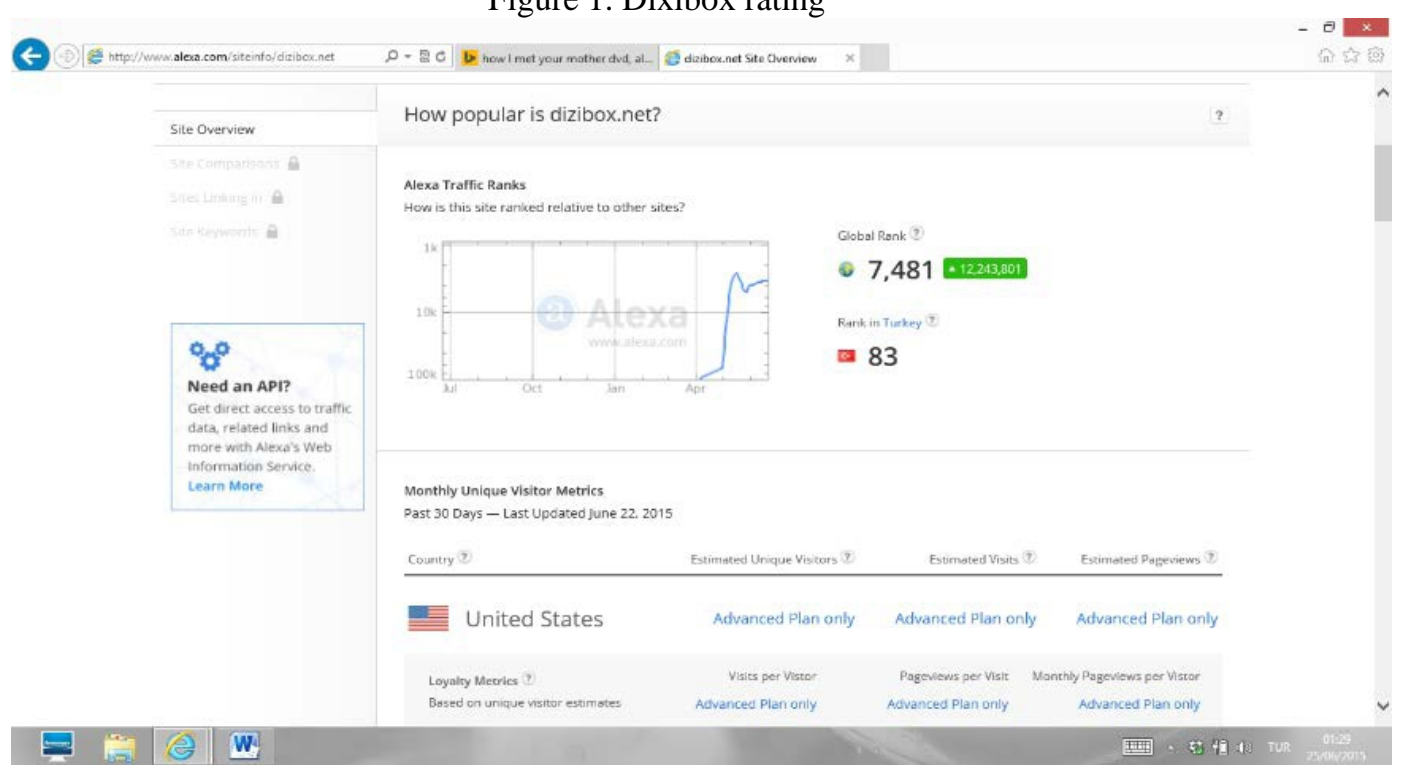

Figure 2. Dizipub rating

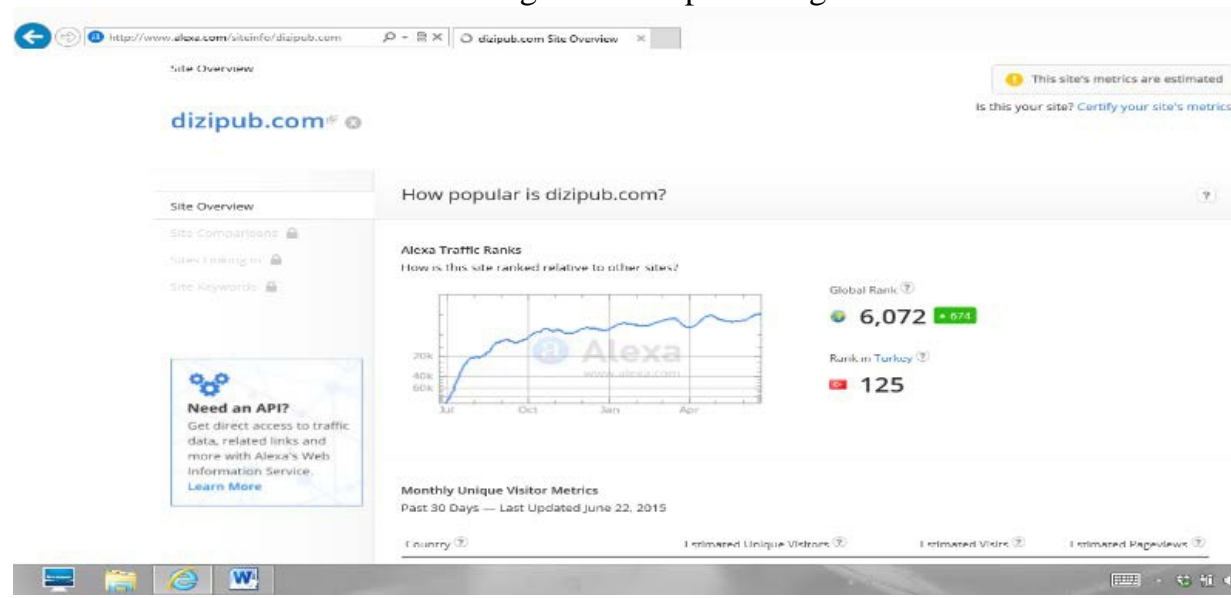

These two sites offer a range of subtitled TV shows including Two and a Half Men.

The availability and the translators of the episodes are as given below in Table 1.

${ }^{60}$ Alexa. An amazon.com company. (Accessed June 25 2015) 
Table 1. Translators of Episodes of Season 12

\begin{tabular}{|c|c|c|}
\hline Ep. & Dizibox & Dizipub \\
\hline 1 & Not available & T. Göktaş \\
\hline 2 & T. Göktaş & T. Göktaş \\
\hline 3 & Not available & Anonymous \\
\hline 4 & T. Göktaş & Anonymous \\
\hline 5 & T. Göktaş & T. Göktaş \& B. Aytekin \\
\hline 6 & E. Ö. Özgan & T. Göktaş \& B. Aytekin \\
\hline 7 & E. Ö. Özgan & T. Göktaş \& B. Aytekin \\
\hline 8 & E. Ö. Özgan & T. Göktaş \& B. Aytekin \\
\hline 9 & Isilwen A & T. Göktaş \& B. Aytekin \\
\hline 10 & E. Ö. Özgan & Wild_cobragirl \\
\hline 11 & E. Ö. Özgan & T. Göktaş \& B. Aytekin \\
\hline 12 & E. Ö. Özgan & T. Göktaş \& B. Aytekin \\
\hline 13 & Isilwen A & T. Göktaş \& B. Aytekin \\
\hline 14 & Isilwen A & Not available \\
\hline $15-16$ & O. Bahadır \& Isilwen A. &
\end{tabular}

For the scope of the analysis section of the study, the subtitled versions in Table 1 and the CNBC-e subtitled version were studied in two initial phases. In the first phase, episodes 11-14 were downloaded from the Internet sites given above. The recorded versions of the episodes on CNBC-e were accessed on the official website, currently providing viewers with the online subtitled versions of the seasons broadcasted ${ }^{61}$.

Subtitles in English for the episodes were downloaded from the Internet, from a site that allows the downloading of the subtitles in multiple languages (Turkish is not an option) ${ }^{62}$. These dialogue lists were used in a comparison of episodes 11-14 with the aim of studying the translations.

In the second phase, the initial findings of the first phase were crossed checked in order to confirm or refute the validity of the findings, with episodes 1-10 from a cross section of subtitled versions of the series. All episodes of season 12 were watched, partially transcribed, and compared with the original as shown in Table 2 below.

Table 2. List of Episodes Reviewed

\begin{tabular}{|c|c|}
\hline Episodes 2,7,8 & CNBC-e subtitles and original compared \\
\hline Episodes 3-5,10 & Dizipub subtitles and original compared \\
\hline Episodes 6,9 & Dizibox subtitles and original compared \\
\hline
\end{tabular}

First of all, in reference to the question on how much was subtitled or what got subtitled, almost every single utterance in the original English version was translated in all the Turkish subtitled versions. According to the

61 CNBC-e Resmi Internet sitesi (Accessed June 25-30, 2015) CNBC-e http://www.cnbce.tv/dizi/728-two-and-a-half-men

${ }^{62}$ TVsubtitles.net (accessed June 25-30, 2015) http://www.tvsubtitles.net/tvshow-56-12.html 
research conducted on subtitling by Sokoli (2009: 46) in Spain to determine subtitlers norms, "the distribution of the subtitles is determined by the acoustic nonverbal (pauses) and the visual nonverbal (cuts) elements. Nevertheless, if there should be a conflict between synchronization of the acoustic and synchronization of the visual, synchronization with the acoustic is the priority in terms of metrical norms.” Also in Spain, in terms of relation norms, few elements as possible are omitted in subtitling. These findings seem to apply to the corpus studied within the context of this study, as almost everything was translated. This having been said, the second question would be under which constraints and conditions were the audiovisual products subtitled.

\section{A Comparison of the Constraints of the Social Translation vs. the Institutional Translator}

As Zabalbeascoa (1996:235) states, the criteria for judging a translation should be clear, flexible, and realistic. It should take into account the translator's limitations and working environment. The constraints on the professional TV channel would be the regular constraints that all subtitlers are familiar with (i.e., the rendering of speech with text, the limitation, and the bonus of having the visual track). Also, in the case of Turkey, the subtitler from CNBC-e would have to censor the text.

At this juncture, Turkish terrestrial TV policy needs to be explained. RTÜK, an acronym in Turkish for the Turkish Radio and Television Supreme Council ${ }^{63}$, is a state agency for monitoring, regulating, and sanctioning radio and television broadcasts. This Council is sensitive about the airing of shows that contain sexual references and elements during the time period when youth, families, and conservative audiences may be watching TV. This organ of the state is an example of those referred to by Lefevere $(1992,15)$ as being a 'power' that can hinder or further material to be accessed by the public.

Bucaria (2009:19) states that the scheduling of TV series on Italian channels may also account for censoring needs and that satellite channels are more tolerant of swearword use than their terrestrial counterparts, and the same may be said of sexual references on Turkish channels, as there is more censoring on terrestrial channels during prime time slots. Bucaria (2007:235) argues that, humour and censorship are two historically interconnected issues and next to literature the media is one of the fields in which censorial intervention of humour has been the most active.

There have been numerous studies on the interconnection of censorship and audiovisual texts (Grieveson 2004), censorship and

\footnotetext{
${ }^{63}$ http://www.rtuk.org.tr/Home/SolMenu/5386\#
} 
translation (Janson 2005) in translation studies. On the other hand, in Turkey, a country where there is censorship on almost all major TV channels due to RTÜK, not much attention has been devoted to the often ambiguous relationship between the censoring of audiovisual texts and humour.

In translation studies, however there is a large amount of work on censorship. For example, Fawcett $(1995,177)$ refers to power plays in translation where the original is manipulated for many reasons including the desire to follow perceived norms. In this case, it entails the protection of family values, as RTÜK censors references to sex and related taboo subjects (i.e., homosexuality in the case of Turkey) on TV during certain hours. In this vein, Seruya (2008, xii) refers to the type of censorship employed by RTÜK as "institutionalized censorship".

In the case of the subtitler for CNBC-e, one cannot preconceive automatically that it was the subtitler himself who did the censoring. It might have been the channel or it may have been a cooperative effort asking the subtitler to reedit his subtitles. With reference to this, Toury $(1995,278)$ refers to postediting practices where the translator himself or another agent who may have a different type of training, is charged with the duty of editing the text according to the acceptable norms. This may have well been the case too. At this juncture, it does not really pertain to the study whether it was the subtitler himself or the editor who did the censoring. What is relevant is the fact that there is censoring in the finished subtitled product.

On the other hand, in terms of the subtitlers for the Internet sites, their constraints would be different from those of the professionals who are working for the TV channel. These social translators would not be working with a backup team like an editor and a person to correct the typing mistakes since this is not an institutionalised structure. Most importantly, there are time constraints since these shows appear with subtitles 24-48 hours after their original airing; as was exemplified in the research into these sites which state that 'time is of the essence'.

At this point, one other fact needs to be underlined, and that is that, in Turkey, there seems to be a standard concerning subtitling of sitcoms, as almost all examples, be it on the Internet, on TV or DVD, seem to have what Diaz Cintas (2009, 80-81) refers to as "a code of good subtitling practice," with due attention to spatial and temporal dimensions, punctuation and other conventions. Technically, the standards are high, but of course with the time limitations placed on the Internet subtitlers and also the fact that there is no editorial team, the subtitles may inevitably contain wrong spelling punctuation and spacing in some instances.

One other difference between the constraints on the two profiles of subtitlers would be that, the translators of the Internet platforms would also be able to gauge their audience expectations better. This is because their 
audience would be composed of educated people who would be able to use the Internet and also probably have a better understanding of a foreign culture due to their level of education. Gambier (2003: 179) refers to accessibility of screen translation covering acceptability, legibility, readability, and relevance. Within the scope of relevance for the viewers, in this context for example, the translators for the Internet left all American cultural references such as Hallmark cards, Hershey's chocolate, Hooters, and Pretzels in the original language. On the other hand, the translator for the TV channel also had to consider how to relate these and in each case gauge whether his much larger audience group would know all of these or not. Furthermore, in his taxonomy of humorous elements, Martinez-Sierra (2006:290) refers to community and institutions elements, community- sense of humour elements, linguistic elements, and non-marked humorous elements. The translator for the TV, as opposed to the Internet translators, would also have to take the first two categories of elements into consideration when translating and would not have the liberty to assume the viewers would know; whereas for the subtitlers for the Internet this would not be a central concern as with the previous examples explained.

\section{Comparative Analysis of the Subtitled Version}

In view of these constraints, the subtitled versions were assessed under three headings. These are:

a. Was there censoring that impaired the understanding and appreciation of the audience?

b. Were there mistranslation? For example, translating 'tables' as 'house' when the translator had ample space for translation and when there is no reason to do so like creating a comical effect.

c. Were there any typing mistakes, wrong spacing, and wrong punctuation which would complicate the reading of the subtitles?

The reason behind the use of these three broad headings for analysis is the presumption that viewers are mainly concerned with two things when they are watching a sitcom: Do I get the joke, is it funny? Can I understand the subtitle without having to spend time to interpret/understand/correct the translation in their minds? Viewers watch sitcoms to enjoy themselves. It is clear that this is not a genre in which they want to think long and hard to be able to understand the discourse, and the above given criteria judges this.

\section{Censoring}

There was no censoring on any of the episodes on the Internet sites, but there were many cases of censoring for the subtitled version on CNBC-e.

Since we are assessing whether or not the viewers have the information from which to understand the story or the joke, as that forms the 
basis of enjoying a sitcom as a viewer, it would not be correct to assume that every instance of verbal censoring (cutting out of the dialogue, a reference or unit etc. in the subtitles) detracts from the meaning conveyed.

Taylor (2003, 194) refers to Thibault's methodology in explaining that that there are various kinds of semiotic resources available to viewers when watching audiovisual material and these combine to form meaning; partial omission or the use of a euphemism in instances where all these come into play may not in this sense really lead to impaired understanding or a loss of comical effect. The following example is an illustration of this:

\section{Episode: 13- 00:02-00:21}

Scene: Lindsey and Alan are relaxing just as the camera moves to a close up of the bed implying that they have just had sex. Lindsey is referring to the fact that since they have been together before, the sex is better. Alan is agreeing with her and stating that knowing what the other person likes is definitely a plus, adding a funny remark like "which leg they can put behind their head" implying a position that sounds strange.

Lindsey: Sex is so much better $\quad$ Lindsey: Tanıdığın biriyle with someone you know well... Alan:..It's true. Sex is better when you, you know, know the other persons rhythms, what they like, which leg they can put behind their head. olmak çok daha güzel.

Alan:... Ama sonuçta karş1 tarafı bilince daha güzel. Temposu olsun, nelerden hoşlandığı olsun, akrobatik hareketler olsun.
Lindsey: It's so much better to be with someone you know.

Alan:... But it is better with someone you know. Their tempo, what they like, the acrobatics.

In the above given example, there is no reference to 'sex' in the translation, it is euphemised into 'being with someone' and 'it'. Also, there is no reference to 'which leg they can put behind their head', but a reference to 'acrobatics'. In this case, since the couple are in bed and since it is clear that they are referring to sex throughout the dialogue, the reference is clear in the subtitled version and the joke is still retained with a joke. Due to the fact that it is clear in the visual (setting) that they have had sex, this fills in the gaps the censoring has cut out. These types of instances of censoring cannot really be considered as examples where the censoring has impaired the conveying of the comical or the transfer of meaning.

In other cases, the cutting out of references to sex and homosexuality, which are prevalent throughout the series studied, does detract from the meaning. The following is an example of this:

\section{Episode 12: 00:08:12}

Walden is scolding Alan because he is sleeping with their social worker and Lindsey at the same time. Walden believes that if the social worker finds out, this might jeopardize his adoption of Louis. The following is a part of the dialogue in which Walden is raising his voice to Alan in their sitting room. The line is followed by a laugh track.

\begin{tabular}{c|c|c}
$\begin{array}{c}\text { Walden: Alan, I want you to } \\
\text { get your penis out of my } \\
\text { business. }\end{array}$ & $\begin{array}{c}\text { Walden: Peşinen söyleyeyim } \\
\text { benim işime sakın burnunu } \\
\text { sokma. }\end{array}$ & $\begin{array}{c}\text { Walden: I’m telling you } \\
\text { upfront, don't stick your } \\
\text { nose in my business. }\end{array}$ \\
\hline
\end{tabular}


In the case of the example given above, the setting does not help the viewers in understanding the joke with the replacement of 'get your penis out of my business' with 'get your nose out of my business'. This is a funny line because Walden is referring to Alan being with two women at the same time. The laugh track that follows is 'meaningless' for the Turkish viewers unless they suppose that the original viewers are laughing at Walden scolding Alan as the subtitle makes no reference to 'penis'.

If only the cases where the laugh track was 'meaningless', like the example given above, were to be taken into account throughout the episodes, the following Table 4 is a count of instances in which the CNBC-e subtitles leave the viewer with fewer jokes than the original.

Table 4. Censoring in CNBC-e

\begin{tabular}{|c|c|}
\hline Episode 11 & 20 \\
\hline Episode 12 & 18 \\
\hline Episode 13 & 14 \\
\hline Episode 14 & 16 \\
\hline
\end{tabular}

One other point that needs to be mentioned is that, in view of the fact that there were no instances of censoring in the Internet versions, it becomes clear that in this context, we are not referring to 'the Turkish subtitlers general tendency for self-censorship in sex related matters' as Santaemilia (2008) would refer to it. This is an example of institutionalised censoring, which when there is no institution to account to, as is the case with the subtitlers on the Internet, censoring is not the first choice of the social subtitlers in Turkey.

\section{Correctness of the Message}

The second category of analysis would be the correctness of the translation. Correctness in translation of humour or in the subtitling of sitcom may not refer to a line by line comparison on the basis of equivalence that one could use, for example, to assess the technical translation of a manual. Of course, one must accept that in the context of the genre (sitcom) and the translation mode (subtitling), there is domestication and the use of creative translation strategies in the conveying of humour. Only instances where the deviation from the original does not contribute to this might be labelled as mistranslations. In the CNBC-e version, there is no mistranslation per se; only the cases of euphemisms, missing units or parts referring to sex and homosexuality due to censoring. These are not instances where the translator has gotten the message wrong, but instances of the application of a systematic translation strategy of the channel. On the other hand, there are translation mistakes in the subtitles on the Internet. It would be easier to exemplify what types of mistranslations are referred to. 


\begin{tabular}{|c|c|c|}
\hline \multicolumn{3}{|c|}{ Dizibox - Episode 11-254 } \\
00:09:49,507 --> 00:09:51,507 \\
\hline I used to bang his sister. & $\begin{array}{c}\text { Kiz kardeşine } \\
\text { çakarmış. }\end{array}$ & BT- He used to bang his sister. \\
\hline
\end{tabular}

In this translation, the man who is sleeping on the coach in the scene is said to be having intercourse with his own sister which makes it incest and maybe not funny, but disturbing. This is not the case in the original, as the speaker is implying that he used to have sex with the sister of the man that is sleeping on the couch in the scene. Hence, this makes it funny because he is sleeping with his friends' sister behind his back.

Scene: Lindsey asks Alan why they drove 2 hours to come to a fish restaurant when they

live on the seaside. Alan explains that this cheap restaurant he has chosen allows him to bring his own wine. Thus, he does not have to pay a corkage fee, which makes it appealing for Alan who is a cheapskate.

\begin{tabular}{|l|c|c|}
\hline \multicolumn{3}{|c|}{ for Alan who is a cheapskate. } \\
\hline Dizipub- Episode 12-390 00:13:34,533 --> 00:13:36,166 \\
\hline no corkage fee. & Tipaya gerek yok. & BT- no need for a cork \\
\hline
\end{tabular}

Alan is boasting about coming to a restaurant where he can bring his own wine. As a result, he does not have to pay a corkage fee. He is not saying that he does not need a cork. The sudden reference to the cork cannot be understood within the context of the scene explained. This is a joke about Alan being stingy and finding a way not to pay for a corkage fee even if he has to drive 2 hours away from the sea to eat fish. This is not relayed in the translation. The translation makes no sense to the target viewers.

\begin{tabular}{|c|c|c|}
\hline \multicolumn{2}{|c|}{ Dizibox- Episode 13-329 00:12:35,100 --> 00:12:37,301 - 330 00:12:39,369 } \\
\hline $\begin{array}{c}\text { Okay, buddy, here we go. } \\
\begin{array}{c}\text { This is the first time } \\
\text { we're walking into this house } \\
\text { as an official family. }\end{array}\end{array}$ & $\begin{array}{c}\text {. ilk defa bu eve } \\
\text { resmi bir olarak } \\
\text { giriyoruz }\end{array}$ & $\begin{array}{c}\text { BT- It is the first time we enter this } \\
\text { house as official one. }\end{array}$ \\
\hline
\end{tabular}

Due to the missing unit, 'family', the translation is not a meaningful sentence in Turkish and means nothing to the Turkish viewers.

\begin{tabular}{|c|c|c|}
\hline \multicolumn{2}{|c|}{$\begin{array}{c}\text { Scene: Mrs M has cooked a dinner that Walden would like and she says that she has a } \\
\text { dessert he will love. To which he respond with enthusiasm thinking it is his favourite- } \\
\text { grandma style apple pie. At which point she strips implying that she is the dessert. }\end{array}$} \\
\hline \multicolumn{2}{|c|}{ Dizipub- Episode 13-185 00:07:07,699 --> 00:07:09,799 } \\
\hline $\begin{array}{c}\text { Did I tell you } \\
\text { about Gam-Gam's apple pie? }\end{array}$ & $\begin{array}{c}\text { Alman fahişenin } \\
\text { elmalı turtasını } \\
\text { anlatmıs mıdım? }\end{array}$ & $\begin{array}{c}\text { Did I tell you about the German } \\
\text { whores' apple pie. }\end{array}$ \\
\hline
\end{tabular}

In the example, Gam Gam is the nickname Walden uses to refer to his grandmother, which the translator would have known if she had watched all the series. He is not referring to a German woman. This is a misunderstanding on the part of the translator. 


\begin{tabular}{|c|c|c|}
\hline \multicolumn{3}{|c|}{ Dizipub \& Dizibox-Episode 14- 27700:11:27,763 --> 00:11:29,831 } \\
\hline $\begin{array}{c}\text { Also, do you } \\
\text { validate? }\end{array}$ & $\begin{array}{c}\text { Dizibox: Orijinallik belgeniz var } \\
\text { mı? }\end{array}$ & $\begin{array}{c}\text { Dizibox: Do you provide } \\
\text { certificates of authenticity? } \\
\text { Dizipub: Do you evaluate value? }\end{array}$ \\
\hline & $\begin{array}{c}\text { Dizipub: Değer biçme işi yapıyor } \\
\text { musunuz? }\end{array}$ & \\
\hline
\end{tabular}

There is a mistranslation in both versions as Alan is asking whether the store will validate his parking ticket which he shows to the store owner, so he can park for free. He is not asking for a certificate as both translations seem to imply. The joke in this instance is about Alan wanting to buy a very expensive engagement ring from a posh store, but asking them to validate his measly parking ticket. Again, it is a reference to his stinginess. Alan asking the store to provide certification for authentication as the translation implies is not a joke, as this is a regular question one would ask at a jewellery store.

As the examples are used to demonstrate, in referring to mistranslations, we are referring to instances where the source text was clearly misunderstood or mistranslated by the subtitlers and not the use of creative translation strategies used to translate a joke with a joke, or the deletion of units due to spatial constraints in subtitling, or the neutralization of culture marked elements for the domestication of the text or any other such endeavour on the subtitlers part. Table 5 presents the number of mistranslations like the examples given above, per episode in the different subtitled versions on the Internet.

Table 5. Mistranslations

\begin{tabular}{|c|c|c|c|c|}
\hline & Episode 11 & Episode 12 & Episode 13 & Episode 14 \\
\hline Dizibox & 8 & 9 & 3 & 2 \\
\hline Dizipub & 12 & 11 & 21 & 8 \\
\hline
\end{tabular}

Since there are approximately 2063 dialogue boxes in the four episodes, the findings according to correctness by percentage are as given in Chart 1 below.

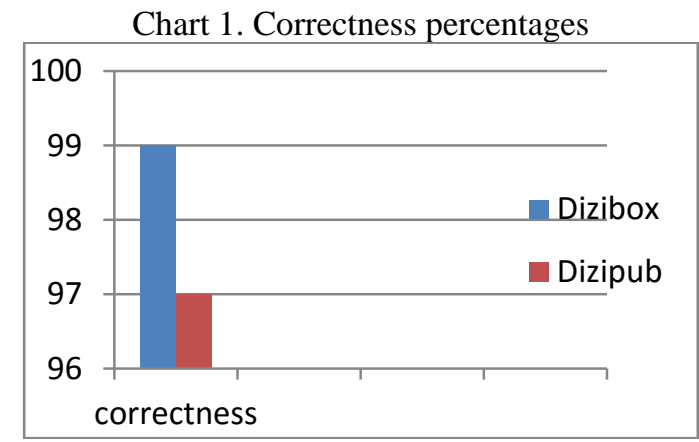


Having provided data about the correctness on the level of content, the next question would be the correctness of the script. This involves the correct use of spelling, punctuation, and spacing.

\section{Correct Use of Spelling/Punctuation/Spacing}

In reference to spelling and punctuation errors or spacing mistakes, one may argue that viewers will only be annoyed by this, but that they will be able to correct the subtitles as they read, as long as the error in question does not impair understanding. This is evident, but it may also be argued that simple errors detract from the subtitling quality of the product and this is not preferred in a subtitled AV product. Thus, the examples have been included in the analysis. No examples are provided, as the notion of a spelling mistake (i.e., spelling 'king' as 'kign' for example) is universal. The figures in Table 6 entitled Legibility present instances where there is either a spelling or punctuation error (i.e., use of an exclamation mark instead of a question mark etc.), spacing mistake (i.e., writing 'themistake' vs. the correct version 'the mistake' etc.).

Table 6. Legibility

\begin{tabular}{|c|c|c|c|c|}
\hline & Episode 11 & Episode 12 & Episode 13 & Episode 14 \\
\hline CNBC-e & 0 & 0 & 0 & 0 \\
\hline Dizibox & 1 & 1 & 6 & 3 \\
\hline Dizipub & 6 & 2 & 6 & 1 \\
\hline Dizimag & 6 & 2 & 6 & 1 \\
\hline
\end{tabular}

Since there are approximately 2063 dialogue boxes in the four episodes, the findings according to language by error count are presented in Chart 2.

Chart 2. Legibility Error Count

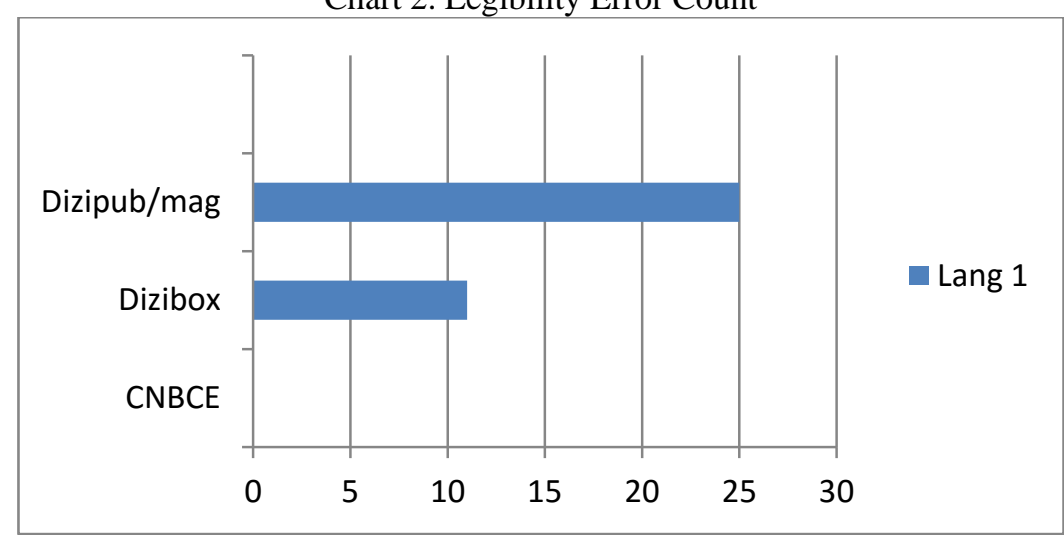

Before moving on to the assessment of the data, one fact needs be underlined: Though viewers do not conduct research on the quality of translation on the basis of categorised mistakes, they are as able as the 
professional translators to judge a product. Hence, there is a clear message that Dixibox, which rates highest in terms of translation correctness, also ranks higher on the Web when compared to other Internet sites like Dizipub when it comes to delivering a usable product. Though in terms of content, technologically and access wise, it does not provide anything different from its counterparts, it is still the most preferred site. In terms of the staff translator for the TV channel, he also probably played a part in the fact that CNBC-e aired twelve seasons of Two and a Half Men during the prime time evening slot.

\section{Conclusion}

In looking at the data, it is clear that the professional translator of the TV channel was hindered by the censorship policy of the channel. This is well known by Turkish viewers as the channel in question tends (like many other channels of its ilk in Turkey) to censor shows. With reference to the translator for CNBC-e, the case is not one of incompetence, since the translator tried to render humour despite the tight leash and even with all the censoring the show was a hit.

With reference to the versions by social translators at this juncture, one must agree with Kuhiwczak (2011, 358) that the widespread access to the Internet have changed issues about censorship as "restrictions on what could be stated in print, in public spaces, or on terrestrial radio and television channels" no longer have the impact they used to. As can be seen from the example studied, one official version may be censored, but there may always be other versions on the Internet.

In reference to the interconnection between censoring and sitcoms, this seems to open up new vistas. Asimakoulas (2004:823) states that a translated joke is an ideal translation when it shares the same script opposition (sexual vs. non sexual readings), thus there can be no ideal translation with censorship, especially with a genre like sitcoms were sex is one of the major subjects of the jokes. According to Kuhiwczak (2011, 363), when censorship is undertaken across language barriers, it may remain largely invisible. However, this is not the case in sitcoms with the laugh track in the background and the uncensored versions on the Internet.

With reference to the use of language, according to Zaidan et al. (2011:1220), collecting translations by crowdsourcing the task to nonprofessional translators yields low quality results if no quality control is exercised. This is also true of social translation where there is no vicious language editing or quality control. Hence, the findings of the language category of the evaluation are higher when compared to the TV channel. It may be safe to say that generally, these social translators with relatively less 
experience than their counterparts who are staff translators for channels who subtitle for a living.

As Vandaele (as quoted in Peyroux, 2011) points out, translation of humour requires a lot of flexibility and imagination from translators. In light of this consideration, we have a variety, two versions of flexibility and imagination within the different constraints of the subtitling realities surrounding production of the same product in Turkey, and both have an audience.

On the one hand, we have the viewers and the national decision makers who expect sitcoms to be suitable for family consumption; and on the other hand, we have another group of viewers and a group of Internet channels who just want to laugh at the jokes and enjoy sitcoms. It is due to the rise of social translation practices and the rise in the use of technology that viewers now have a choice to bypass top-to-down socio-political policy surrounding translation norms, especially in terms of censoring policies in Turkey.

In the case of Turkey and subtitled sitcoms, the decision to watch sitcoms online or on TV probably depends on your taste in comedy and what you expect to get: The professional subtitler gives you all the jokes albeit in a roundabout way, the social translators may make some mistakes, may be 'clumsier with language' in some cases, but the essence is there.

Furthermore, as the statistics in the study seem to imply, these are not marred by the brush of an amateur to the extent that social practices of subtitling seem to imply for some scholars, professional translators, and probably even viewers (who may see the product of a social translator as something clumsy), who have preconceived prejudices for this type of practice. That is not to say there are no mistakes, but the extent to which these effect the overall quality of the subtitling of a sitcom within central considerations of viewers like 'it should reflect the humour' is dubious.

More importantly, these subtitlers both find an audience. One of the contributions of the social translation sector to Turkish viewers is that, now, those who do not want to be censored when watching sitcoms, have the opportunity to bypass official censors through social translation practices on the Internet. The audiovisual product that they watch may not be a flawless translations- but with a sitcom the priority is not necessarily on absolute equivalence, which by the way censoring also hinders, but more about laughing and enjoying oneself. Both versions seem to live up to this standard, albeit in different ways.

\section{References:}

Asimakoulas, D. (2004). Towards a Model of Describing Humour Translation: A Case Study of the Greek Subtitled Versions of Airplane and 
Naked Gun. In Meta: Translators Journal Volume 49 Number 4. XLIL: 822842. Les Presses de L'universite de Montreal. DOI: 10.7202/009784ar.

Bogucki, L. (2009). Amateur Subtitling on the Internet. In Audiovisual Translation: Language Transfer on Screen, ed. by J. Diaz Cintaz \& Gunilla Anderman, 49-57. UK: Palgrave Macmillan.

Bucaria, C. (2007). Humour and other catastrophes: dealing with the translation of mixed-genre TV series. Journal Linguistica Antverpiensia, New Series, Volume 6, 235-254.

Bucaria, C. (2009). Translation and censorship on Italian TV: an inevitable love affair? In VIGO International Journal of Applied Linguistics (VIAL), 2009/6, 13-32.

Diaz Cintas, J. and A. Remael. (2009). Audiovisual Translation: Subtitling. Manchester UK: St Jerome Publishing.

Dodd, S. M. (2011). “Crowdsourcing: Social[ism] Media 2.0”, Translorial: Journal of the Northern California Translators Association. http://ranslorial.com/2011/01/01/crowdsourcing-socialism-media-2-0/ Last accessed 13 March 2012.

Fawcett, P. (1995). Translation and Power Play. In The Translator. Studies in Intercultural Communication. Ed. By Mona Baker. Vol 1, No2. Manchester St. Jerome Publishing, 177-192.

Gambier, Y. (2003). "Introduction”. In The Translator, 9:2, 171-189. DOI:10.1080/13556509.2003.10799152.

http://dx.doi.org/10.1080/13556509.2003.10799152.

Gence, H. (2009). Altyazı Üstatları. Hürriyet 18 Ocak 2009. http://www.hurriyet.com.tr/pazar/10795574.asp

Grieveson, L. (2004). Policing Cinema. Movies and Censorship in the Early Twentieth Century America. Berkeley/Los Angles: University of California Press.

Hessellund, L. T. (2014). Crowdsourcing in the Translation Industry- an Emerging Trend in a Globalised World. 7 Aug 2014. Aarhus University. BSS. Department of Business Communication. http://pure.au.dk/portal-asbstudent/en/studentprojects/crowdsourcing-in-the-translation-industry--anemerging-trend-in-a-globalised-world(9ffc3a05-0357-4837-ad663148903c7988).html.

Howe, J. (2008). Crowdsourcing: How the Power of the Crowd is Driving the Future of Business. London: Random House Business Book.

Jansen, P. (ed.) (1995). Translation and the Manipulation of Discourse. Leuven: CE-TRA the Leuven Research Centre for Translation, Communication and Cultures.

Kuhiwczak, P. (2011). Translation Studies Forum: Translation and Censorship. Translation Studies, 4:3, 358-373. 
Lefevere, A. (1992). Translation, Rewriting and the Manipulation of Literary Frame. London-New York: Routledge.

Martinez-Sierra, J. J. (2006). Translating Audiovisual Humour: A Case Study. In Perspectives: Studies in Translatology, 13:4, 289-296. DOI:10.1080/09076760608668999. http://dx.doi.org/10.1080/09076760608668999.

McDonough Dolmaya, J. (2012). Analysing the Crowdsourcing Model and Its Impact on Public Perception of Translation. In The Translator, 18:2, 167191.

DOI:10.1080/13556509.2012.10799507.

http:// dx.doi.org/10.1080/13556509.2012.10799507.

Mesipuu, M. (2010). Translation Crowdsourcing- an Insight into How's and Whys. Unpublished Masters Thesis in Tallinn University Institute of Germanic Romance Languages and Cultures. http://e-ait.tlulib.ee/156/.

O’Hagan, M. (2003). Middle Earth poses challenges to Japanese subtitling. In LISA

Newsletter

XII.

www.lisa.org/archive_domain/newsletter/2003/1.5/ohagan.html.

O’Hagan, M. (2009). Evolution of user-generated Translation: Fansubs, Translation hacking and crowdsourcing. In Journal Of Internationalisation and Localisation 1(1), 94-121. http://pablomunoz.com/wpcontent/JIal_2009_1_2009_aPa.pdf. Last accessed 13 March 2012.

Peyroux, R. (2011). Subtitling American Comedy Programs into French. USA: University of Massachusetts.

Pym, A. (2011). What Technology does to Translating. In Translation \& Interpreting, Vol 3. No 1, 1 -9.

Santaemilia, J. (2008). The Dangers of Self Censorship: The translation of 'Fuck' into Spanish and Catalan”. In Translation and Censorship in Different Times and Landscapes. Ed. By Teresa Seruya and Maria Lin Moniz, 163-173. UK: Cambridge Scholars Publishing.

Seruya, T. (2008). Foreward. In Translation and Censorship in Different Times and Landscapes. Ed. By Teresa Seruya and Maria Lin Moniz. UK: Cambridge Scholars Publishing. xi-xix.

Sokoli, S. (2009). Subtitling Norms in Greece and Spain. In Audiovisual Translation: Language Transfer on Screen, ed. by J. Diaz Cintaz \& Gunilla Anderman, 36-48. UK: Palgrave Macmillan.

Taylor, C. (2003). Multimodal Transcription in the Analysis, Translation and Subtitling of Italian Films. The Translator. Volume 9, Number 2 (2003), 191-205.

Toury, G. (1995). Descriptive Translation Studies and Beyond. Amsterdam/Philadelphia: John Benjamins.

Zabalbeascoa, P. (1996). Translating Jokes for Dubbed Television Situation Comedies. In The Translator, Volume 2, Number 2, 235-257. Manchester: St Jerome Publishing. 
Zaidan, O and C. Callison-Burch. (2011). Crowdsourcing Translation: Professional Quality from Non-Professionals. In Proceedings of the 49th Annual Meeting of the Association for Computational Linguists, 1220-1229. Portland Oregon June 19-24, 2011.

\section{Chats}

Chat 1. http://forum.altyazi.org/index.php?showtopic=215188 (last accessed 22 July 2015)

Chat 2. http://forum.altyazi.org/index.php?showtopic=215188 (last accessed 22 July 2015)

Chat 3. http://www.yeppudaa.com/showthread.php?t=59279-eviri-yapmakistiyorum (last accessed July 22 2015)

Chat

4. http://www.emailmeform.com/builder/form/O798ea6VwqfHbb0p7d5a (last accessed July 22 2015)

Chat 5. http://www.eksiduyuru.com/duyuru/363949/ceviri-ucreti-dizimag (Last accessed July 22 2015)

Chat 6. http://www.r10.net/is-verenler/1387685-yabanci-dizi-sitesi-icincevirmenler-araniyor.html (last accessed July22 2015)

Chat 7. http://mobile.donanimhaber.com/showTopic.asp?m=76473355\&p=1\#76473 355 (last accessed July 22 2015)

Chat 8. https://eksisozluk.com/dizi-cevirmenligi--4508928 (last accessed July 22 2015)

Chat 9. http://www.r10.net/farkli-dillerde-makale-yazimi-ampsatisi/1439550-dizi-sitesi-altyazi-cevirmenligi-ucretsiz.html (last accessed July 22 2015)

Chat 10. http://forum.altyazi.org/index.php?showtopic $=173412 \& s t=0$ (last accessed July 22 2015)

Chat 11. http://www.eksiduyuru.com/duyuru/291293/altyazi-cevirmenligi (last accessed July 22 2015) 